этого заб̆левания являются медленно нарас:ающие боли ишналыгичсского дарағтера, даящисся от нескольких месяцев до двух лет. Иногда ранним скипто-

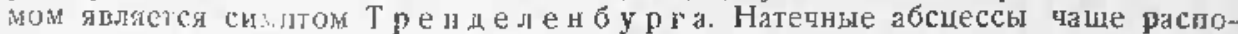

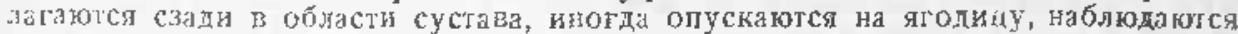
также прорывы кпереди. Личелие применяется как оперативное (иссечение н выскабынвание свилей, удаление ссквсслров, резекция костй), так и консервативное (Е.гиване в свини иодоформ-пидериновой эмунисии, рентген). Ав-

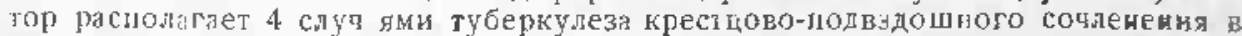
возраяте 19-66 лет. Во всех слуцая наблюдалось улучшсние процесса посые лечения, холя нужно иметь в виду, что для туберкулезл нодвздошно-крестио. вого сочленсиия вообще характерны длительные ремиссии Хронитеский остеомиени крсстцово-подвздошного сочлешения автор наблюдал у одного больного. Диагноз был поставлен на основании рептеновского, бактериологического и гисгологического исслелования. Через 8 недель после олерация больной был выписан в хорошем состоянии. В пругом спучае диагноз не был уста-

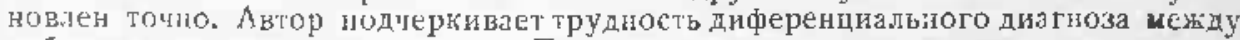
туберкулезом и остеонелитом. Признаки хроническоғо остеомиелита крестцово-подвздониого сочленения заклиочатся в локализирований болезненности шрн давлении, нелрэвильюом положения при стоянии с полной подвнжностью тазобелренного сустдв. Наиболее важным методом исследования является рентғен. Кроме того, автор нлблюдал? случая остеомиелита седалищной косты. 1 больной был въиисан в хорошем состоннии, у второго через полгода после олерации инелся спе свии. Остеомиелит побковой кости авіор наблидал у

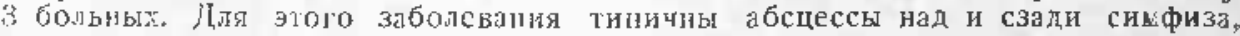

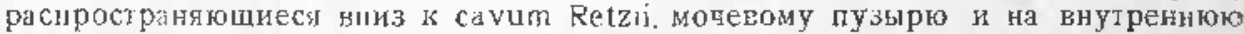
повсрхносіь тяза к запирательному озверстию или на внутрениюю поверхность бсдра к гриволящиы мышдам.

B. $M$.

W a chs, E. I7porpecctpyюuиĭ нежроз кожи. (Br. Beitr. zur kl. Chir. Bd. I65.

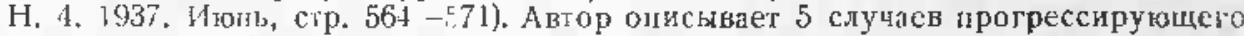
некроза кожи. Нерсз нссколько лней послс олерадии происхолит внезалное разрушение кожи и подкожной клстцати, принимающее прогрессируџщее течение. Һзва раслространяетсл в одну сторону, причем край ее здесь приподинміегя Ilpoгрессируя на одной стороне, язва загнивает на другой после оіторжсиия пекротической ткан. Общее состояние страдает сильно. Обыцио

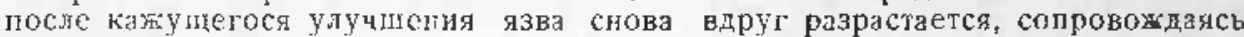
болями и высокой темперлтурой. Возиккиовеиие этих язв наблидается в льбон возрлсте. Причина этою заболевания нсясиа. При бактериологическом исследіовани автор находнл во всех случаях сиешаннуғо инфскцию. На основании палолого-анатонических исследовнний автор объясняет прогрессируюцее течение язви тромбофлеби:ом. Автор считает целесопбразным только радикальное лечение́. Грименявшися виячяле ривановоловые влажные повязки $(1: 1000\}$, переливанис крови и пазначение витаннов давало времсннос улучшение. Јучшим способом автор считаст электрокаустическое исссчсние краев иль. лучце всей язвенной поверхности. Это вмешательство необходимо производить рано. В з спучаях жвтора больные умерли, 2 больных выздоровели посже амПутау.иј конечности.

B. $A 4$.

\title{
в) П7едиатрuя.
}

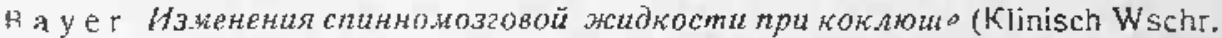
№ 11, 1935). Цавио известны менннгититеские и энцефалитические изменения шри тятелой судорожной форме коклюша. Автор исследовал спинномозтовую 这идкость у жногих больных коклюшен без осложнений со стороны нервной системы и лаходи.т иелый ряд изменений в жидкости: изменение окраски, повышснис давлепия, незначительное увеличсние белка и клеточных элементов. Токситские $\boldsymbol{н}$ чисто трявнатические изменения со стюроны мозговых ободочек и мозга вызынаются повышением внутричерепного давления при пристулах канля и знатительно чаще свойствены коклюшу, џем думали до сих пор.

UV. Геллер.

Blo is e и Pe rez. Эфирные клизиь при коклюие. (Arch. Pediatr. Uruguay. V. 8, III, 1937). Авторы предложили при коклюше вволить ктизмы следующего состава: $20 \mathrm{cм}^{3} 10 \%$ раствора камфоры в эфире, $30 \mathrm{r}$ айкалиптола и 100 сж" 4\% раствора ароматического мзсла в жидком петролате. Жидкость эта вволится в прямуг кишку при понощи нелатоновского катетера № 14 и 16 на глубнну 